\title{
Evaluating Sire Selection Practices Using Lifetime Net Income Functions
}

\author{
B. G. Cassell, S. M. Jobst, M. L. McGilliard, and R. E. Pearson \\ Department of Dairy Science \\ Virginia Polytechnic Institute and State University \\ Blacksburg 24061-0315
}

\begin{abstract}
Dairy farmers do not take full advantage of opportunities available for genetic improvement through use of artificial insemination, perhaps because economic advantages of good sire selection may not be fully recognized or understood. This study was undertaken to document differences between use of AI and non-AI bulls and to develop prediction equations to compare lifetime economic merit of future progeny from alternative sire selection policies. We describe the use of two methods of measuring lifetime economic merit, with and without adjustment for opportunity cost of a postponed replacement. Comparison of lifetime relative net income adjusted for opportunity cost on groups of cows sired by different kinds of bulls showed that daughters of proven AI bulls generated $\$ 148$ and $\$ 120$ more lifetime net income under fluid and manufactured milk market conditions than daughters of non-AI bulls. Daughters of proven AI bulls produced $\$ 60$ more than daughters of AI young sires in progeny testing programs at the time of daughter conception. We developed prediction equations from combinations of genetic evaluations for production, productive life, SCS, and linear type traits on sires to predict lifetime relative net income of progeny produced from alternative sire selection strategies. Prediction equations explained 14 to $18 \%$ of variation in relative net income (not adjusted for opportunity cost), but herd and year of first freshening accounted for considerably more variation than did genetic evaluations on the sire of the cow. Finally, two independent data sets were used to develop and test predictions of lifetime relative net income adjusted for opportunity cost using genetic evaluations based on the eight traits included in the Merit indexes for the sire of each cow. Prediction equations from odd numbered herds were used to predict lifetime economic merit in even numbered herds and vice versa. Coefficients of determination ranged from 0.088 to 0.103 and averaged 0.004 higher than prediction equations with Net or Fluid Merit. Accuracy
\end{abstract}

Received April 10, 2002.

Accepted June 24, 2002.

Corresponding author: B. G. Cassell; e-mail: bcassell@vt.edu. of predictions showed that Net and Fluid Merit were robust and useful indexes that accurately identified bulls whose daughters generated highest lifetime economic merit.

(Key words: lifetime profit, Net Merit, sire evaluations)

Abbreviation key: DPL = days of productive life, HYS = herd-year-season, $\mathbf{O C}=$ opportunity cost, $\mathbf{P L}=$ productive life, $\mathbf{R N I}=$ relative net income, $\mathbf{R N I O C F}=$ RNI adjusted for opportunity cost in a fluid milk market, RNIOCM = RNI adjusted for opportunity cost in a manufactured milk market.

\section{INTRODUCTION}

Artificial Insemination has been available to dairy producers for over 60 years in the United States. Benefits of AI for genetic improvement are well established (Van Vleck, 1976; Van Vleck, 1981). The utility of current genetic evaluations for predicting performance of future progeny has also been well documented (Ferris and Wiggans, 1991; Vierhout et al., 1998; Cranford and Pearson, 2001). Despite the evidence of genetic improvement through AI procedures, many producers continue to use natural service to bulls of lesser genetic merit than bulls available through AI. The November 2001 summary of 10,305 herds on supervised DHI testing plans with records processed by DRMS Raleigh showed that $24 \%$ of lactating cows were currently bred to bulls not in AI service. Use of bulls not in AI service increased to $36 \%$ in herds on unsupervised testing plans.

Factors limiting use of AI include misconceptions of the true value of superior AI progeny, labor requirements for heat detection, quality of labor required for success, inability to consistently manage a herd for optimal performance through AI, perceptions of high cost for AI compared to natural service, and delay in receipt of benefits from use of genetically superior bulls. Dairy production is a competitive enterprise in the United States, with low per unit costs of production an essential ingredient for survival of the dairy business. Economic efficiencies of genetically superior cattle, if documented and presented to producers in a readily comprehensible 
manner, might be helpful in encouraging producers to more fully utilize the economic benefits of AI. Relationships between the many traits for which genetic evaluations are available and economic returns through daughter performance are complex and difficult to interpret, as shown by Weigel et al., 1997 and VanRaden, 2000. Long-term economic implications of alternative sire selection policies could be compared if useful prediction equations and estimates of genetic trend for a variety of traits were incorporated into computer graphics programs. Such an approach requires an estimate of lifetime economic merit. One function that has been used in several studies is lifetime relative net income, (Weigel et al., 1995a; Weigel et al., 1995b; Smith et al., 1998). Kulak, 1994, and Charagu, 1997, used similar but separately developed procedures to evaluate lifetime economic merit of dairy cows.

Many researchers and producers have embraced lifetime economic merit as the most useful breeding objective for genetic improvement programs in dairy cattle. VanRaden, 2000, described three indexes (Net, Fluid, and Cheese Merit) that included sire evaluations for production, fitness, and type traits, properly weighted to improve total lifetime economic merit of the dairy cow. References to Merit indexes throughout this manuscript refer to the indexes developed by VanRaden, 2000. Economic weights used in the Merit indexes (VanRaden, 2000) were determined from published research of expected costs and returns similar to Rogers, 1993, and by retrospective evaluations of lifetime economic merit from traits measured early in life similar to Weigel et al.(1995a) and Weigel et al. (1997). Documentation of the utility of the Merit indexes would encourage their utilization in sire selection decisions.

Our first objective in this study was to quantify differences in lifetime economic merit of daughters of bulls with no record of use in AI and bulls in AI service, using an appropriate lifetime economic merit function. Our second objective was to develop equations to predict an appropriate lifetime economic merit function using different combinations of bull proofs for production, fitness, and linear type. Our intent in this objective was to predict response to alternative sire selection practices, rather than to compare economic weights for different traits with the partial regression coefficients. Our third objective was to evaluate the utility of the Merit indexes using an alternative approach to estimate lifetime economic merit of cows. Here, our purpose was to compare the accuracy of prediction of lifetime economic merit by the Merit indexes to alternative weightings of the traits used in the Merit indexes. Ultimately, our purpose was to incorporate findings into a readily comprehensible, graphic representation of long term effects of alternative sire selection strategies that could be shown to producers using microcomputers.

\section{MATERIALS AND METHODS}

\section{Lifetime Relative Net Income}

Our lifetime net income function, lifetime relative net income (RNI) was based on an 84-mo herdlife opportunity. All lactations initiated before a cow reached 84 mo of age contributed to her RNI. Thus, an entire record initiated the day prior to a cow's 84th mo of age would be included while the entire record initiated the day of or after the 84th mo of age would not be considered. Smith et al. (1998) described two forms of the lifetime economic merit function used in this study, RNI and RNI adjusted for opportunity cost. RNI is calculated by the following equation:

$$
\begin{aligned}
\mathrm{RNI} & =\sum_{\mathrm{i}-1}^{\mathrm{n}}\left[\sum_{\mathrm{j}=1}^{3} \text { Component }_{\mathrm{ij}}\left(\text { Value }_{\mathrm{j}}-\text { Cost }_{\mathrm{j}}\right)\right] \\
& +(\text { number of lactations })(\text { net value of a calf }) \\
& + \text { net salvage value }- \text { rearing costs } \\
& -(\text { total days in milk })(\text { daily expenses per day } \\
& \quad \text { in milk }) \\
& -(\text { total days dry })(\text { daily expenses per day } \\
& \text { dry })
\end{aligned}
$$

Summation is over $\mathrm{j}$ components (milk or carrier, fat, and protein) and i lactations initiated before the end of the 84 mo herdlife opportunity. Further details of the economic assumptions summarized here are available (Weigel et al., 1995b). We used two milk prices, one appropriate for manufacturing milk markets and one appropriate for fluid milk markets. Milk prices are represented by "value" in the equation above. Feed costs for production of milk, fat, and protein were determined as suggested by Dado et al. (1994) and are represented by "cost" in the above equation. Protein is assigned a cost of production but has no value in the marketplace in fluid milk markets. Protein has the same cost of production, but also generates income in manufactured milk markets. The net value of the calf included costs to obtain a pregnancy in the dam, sex ratio, differential value of male and female calves, and average death losses. Sex of calf $\times$ lactation was not available. Net salvage value reflects the difference between the value of a fresh heifer and a cull cow, with cull cow value reduced for the average probability of death loss that was constant across cows and herds. Rearing costs were based on age at first freshening. Cows milked three times daily were charged $\$ 3.53 / \mathrm{d}$ compared with $\$ 2.80 /$ $\mathrm{d}$ for cows milked twice daily for labor and facilities involved in milk harvesting. Daily expenses considered 
were labor costs for milking and handling of lactating cows when in milk, with lower costs during the dry period. Daily expenses also included feed costs for body maintenance for days milking and dry and fixed costs for facilities. Actual milk, fat, and protein production for up to the first $305 \mathrm{~d}$ of each lactation was used. All days beyond $305 \mathrm{~d}$ of production were considered to be dry days, even for cows that milked considerably longer than $305 \mathrm{~d}$.

\section{Lifetime Relative Net Income Adjusted for Opportunity Cost}

We estimated opportunity cost (OC) from the average RNI on all heifers that freshened for the first time in each herd and year combination. Days of productive life (DPL) are necessary to calculate OC, and are the interval from first calving to (last calving + DIM for the last record). DPL is calculated differently from Productive Life (PL), the trait used for genetic evaluations of herd life in the United States. PL includes a maximum of 10 mo per lactation, whereas DPL includes the entire interval between first calf and culling or death. We used DPL to calculate OC, but PL for other references to herd life in this study. Opportunity cost was estimated by RNI/DPL, and is thus expressed as a cost per day in the herd. Opportunity cost can only be calculated directly for those herd and year of first freshening combinations that permit an 84-mo herdlife opportunity for first calf heifers. Production records initiated too recently for 84-mo herd life opportunity can contribute to calculation of RNI by the equation above, but cannot contribute directly to estimation of OC. We predicted RNI/DPL for each herd for those more recent years using linear regression from earlier OC for that herd. Details of estimation of OC for recent years are in Smith et al. (1998).

RNI adjusted for OC (RNIOCM for manufactured milk prices and RNIOCF for fluid milk prices) for each cow was the difference in her RNI and her total OC. Total OC was summed across lactations, multiplying the appropriate $\mathrm{OC}$ for the current lactation by the calving interval for that lactation on each individual cow in the study.

RNI increases with genetic trend and, since it is a function of RNI, so does OC. RNIOCM or RNIOCF, however, have almost no trend over time, because both cows born in later years and $\mathrm{OC}$ for those cows increase at a similar rate. RNIOCM or RNIOCF measure the ability of an individual cow to utilize herd resources relative to heifers freshening in the same year. A measure of lifetime economic merit without adjustment for OC (RNI in this study) measures the ability of a cow to generate return above costs, with no consideration for whether another cow would generate more or less return above costs from the same resources. We consider RNIOCM or RNIOCF to be the correct measure of lifetime economic merit to use to evaluate lifetime economic merit of cows from historical data when the objective is to determine the importance of individual traits to lifetime economic merit, or to compare past performance of cows produced by different breeding programs. However, prediction equations for RNI adjusted for OC by methods used in this study are inappropriate for RNIOCM or RNIOF, because the predicted values should sum to zero and display no trend. Prediction of RNI is appropriate and useful as long as it is understood that RNI does not consider alternative uses of the same resources (OC). We use RNI in this paper to predict future response to sire selection practices that remain consistent over time, since sire merit improves with genetic trend. The most appropriate use of such predictions would be to evaluate differences between alternative sire selection protocols, where one system would serve as "opportunity cost" for the other.

\section{Data Used}

Cows included in this study were from herds classified for type by the Holstein Association, Brattleboro, VT, from 1983 to 1990, described in detail by Smith et al. (1998). We did not use any classification scores on females or require that they be scored, but did use genetic evaluations for linear types of traits on sires of cows in those herds. Lifetime production records were obtained from the Animal Improvement Programs Laboratory (USDA, Beltsville, MD), with earliest first calvings in 1983 (birth year 1980), and most recent first calvings in 1991 (birth year about 1988). Calving dates for second and later records continued through 1995. Genetic evaluations for production and fitness traits PL and SCS on sires of cows in the study were provided by the Animal Improvement Programs Laboratory, while genetic evaluations for type on the same bulls were obtained from the Holstein Association. We used the November 1999 genetic evaluations. The age of the data in this study is dictated by herdlife opportunity requirements, a restriction that affects all lifetime performance studies based on field data.

$\mathrm{RNI}$ and RNIOC for fluid and manufacturing milk market prices (four variables per cow) were calculated by procedures described above. Sire evaluations for production, PL, and SCS were merged with lifetime economic merit of daughters, producing records for $2,493,585$ cows in over 129,000 herd-years of first freshening. We used sire identification from cow records and USDA genetic evaluation history files to assign those cows to four groups based on characteristics of the bull 
that sired them. Sires of cows in Group 1 were bulls with no record of ever being in AI service. Sires of cows in Group 2 were in AI service, but were less than 4 years of age at the time the cow was conceived. Our interpretation is that these bulls would have been in an AI progeny test program when they were used. Sires of cows in Group 3 were in AI but were from 4 to 6 years of age at time of conception. Our interpretation is that these bulls were used without benefit of progeny test results, but were probably beyond their initial sampling period. The purpose of creating this group was to prevent such sires from being part of the other two groups of AI sires. Sires of cows in the fourth group were in $\mathrm{AI}$ and at least 6 years of age at time of conception of the daughter. Genetic evaluations based on progeny performance should have been available at the time of use for these bulls, and we interpret results from this group as indicative of response to breeding programs using proven AI bulls.

$$
y_{i j k}=h y_{i}+G_{j}+e_{i j k}
$$

Least squares contrasts between these groups were obtained from model [1] where herd-year of first freshening $\left(h_{\mathrm{i}}\right)$ was absorbed and sire group effect $\left(\mathrm{G}_{\mathrm{i}}\right)$ was fit to various lifetime performance traits of cows. In model 1, $\mathrm{Y}_{\mathrm{ijk}}$ represents RNIOCM, RNIOCF, or another lifetime performance trait of the $k$ th cow calving for the first time in the $i$ th herd and year (absorbed), and sired by a bull in the $j$ th group as explained above with residual error $\mathrm{e}_{\mathrm{ijk}}$. The measure of lifetime economic merit used in this analysis was RNIOC because our interest was in comparing the use of herd resources between different kinds of sire selection policies, rather than in predicting future differences after sire merit changes through genetic trend. We used PROC GLM of SAS (1988) for analysis.

The second objective, predicting future profitability from long-term application of alternative sire selection strategies, used RNI rather than RNIOC as the response variable. The analysis also required a different model and additional restrictions on the data. For Model 2, we required that genetic evaluations for linear type traits be available on sires of cows in the data. This requirement left 2,136,141 cows in over 128,000 herd-years of first freshening. We no longer used the sire group effects described in Model 1 in this analysis. Data included cows sired by 6663 different sires. The model used was

$$
\mathrm{y}_{\mathrm{ijk}}=\mathrm{hy}_{\mathrm{i}}+\sum_{\mathrm{l}-1}^{\mathrm{n}} \beta_{\mathrm{l}}\left(\mathrm{PTA}_{\mathrm{jl}}\right)+\mathrm{e}_{\mathrm{ijk}}
$$

where $y_{\mathrm{ijk}}$ represented RNI (not RNIOC) from fluid or manufacturing milk markets on the $k$ th daughter of the $j$ th sire calving for the first time in herd-year of first freshening $i$. We used three different combinations of genetic evaluations (PTA's) on production, PL, SCS, and linear type traits to predict RNI in fluid or manufacturing milk markets of daughters. Subscript $l$ in equation [2] represents the different traits, and $n$ would vary depending on which of the three combinations of traits was included in an analysis. The effects of herd-year of first freshening were absorbed.

RNIOC from the 2,136,141 records evaluated by model [2] were also used to compare the accuracy of prediction of lifetime economic merit from the USDA Merit indexes to alternative weights applied to the same traits used in the Merit indexes. We divided the 2.1 million cows into two independent data sets of approximately equal size based on last digit (odd or even) of the DHI herd code number. Sire evaluations for the eight traits (or composites of linear type traits) used in the Merit indexes were used in Model 2 to develop two prediction equations, one from odd numbered herds and one from even numbered herds, for RNIOC using fluid or manufactured milk market prices. We then used the prediction equation developed from odd numbered herds to predict lifetime economic merit from genetic evaluations on sires of individual cows in even numbered herds and vice versa. This approach allowed us to predict lifetime economic merit on cows from prediction equations derived from an independent data source. Finally, we fit the linear regression of RNIOC for fluid or manufactured milk market prices on each cow on Net or Fluid Merit on each cow's sire or on our prediction of lifetime economic merit. Herd-year of first freshening was absorbed, as in Model 2 . The $\mathrm{R}^{2}$ values from these prediction equations were used to evaluate relative accuracy of the alternative indexes.

The Merit indexes were not available in the November 1999 genetic evaluations, which we used in this study, as USDA first released them in August 2000. The new formulas (VanRaden, 2000) were available to us and were used. Genetic evaluations from both USDA and HA, Inc. are included in the Merit indexes. One of the type composites used is the Feet and Legs Composite, and it includes the trait "Feet and Legs Score", a relatively recent addition to the type evaluation program of Holstein Association, Inc. Genetic evaluations for Feet and Legs Score is missing on 5099 of the 6663 sires involved, but daughters of those bulls were only $25 \%$ of the 2.1 million cows involved in this analysis. Feet and Legs Composite receives from 3 to $4 \%$ of total emphasis in the Merit indexes and feet and legs score is only half of the composite. Rather than discard a quarter of the data for an item of information that re- 
Table 1. Lifetime performance traits of 2,493,586 Holstein cows with opportunity for 84 mo of herdlife.

\begin{tabular}{lcc}
\hline Variable & Mean & $\begin{array}{c}\text { Standard } \\
\text { deviation }\end{array}$ \\
\hline Relative net income & & \\
$\quad$ Using milk values in a fluid milk market & 1898 & 2003 \\
$\quad$ Using milk values in a manufacturing milk market & 995 & 1377 \\
Relative net income adjusted for opportunity cost & -11 & 877 \\
$\quad$ Using milk values in a fluid milk market & -8 & 738 \\
$\quad$ Using milk values in a manufacturing milk market & 2.8 & 1.7 \\
Number of lactations initiated & 24.5 & 14.9 \\
Months of productive life & & 14208 \\
Lifetime total milk, $\mathrm{kg}^{2}$ & 20588 & 516 \\
Lifetime total fat, $\mathrm{kg}^{2}$ & 746 & 446 \\
\hline Lifetime total protein, $\mathrm{kg}^{2}$ & 651 &
\end{tabular}

${ }^{1}$ Maximum of 10 mo in milk per lactation initiated.

${ }^{2}$ Yields include production through the first $305 \mathrm{~d}$ for all lactations.

ceived little weight, we substituted the average Feet and Leg Score for the 1564 bulls with information available, 0.106, when Feet and Leg Score was missing on the sire of a cow. Other traits in the feet and leg composite were available on all bulls.

\section{RESULTS}

Means for several lifetime performance traits are in Table 1. RNI was larger and more variable when calculated from fluid milk market prices than when calculated from manufactured milk market prices. RNIOCM and RNIOCF were both slightly negative, but very near zero. The standard deviation of RNIOC was considerably less than for RNI. These results are consistent with the findings of Smith et al. (1998) and Weigel et al. (1997) from similar data and procedures. The average cow in these data initiated 2.8 lactations and produced milk for an average of 24.5 mo with a maximum of 10-mo production per lactation. The average of 24.5 mo PL in this study is very close to the Holstein breed average of 24.6 mo used in the 1995 genetic base for genetic evaluations for PL (VanRaden et al., 1995). Lifetime totals for actual milk, fat, and protein production were highly variable across cows in the study. Production beyond $305 \mathrm{~d}$ into lactation was not included in lifetime totals for production.

\section{Comparison of RNIOC in Daughters of Bulls In or Not In Al Service}

Least squares contrasts between groups of cows sired by bulls in or not in AI service are in Table 2. A bull in $\mathrm{AI}$ could contribute information to more than one of the AI groups. For instance, some daughters in the data may be first crop progeny while others result from use of the bull following publication of progeny test results. We used genetic evaluations from November 1999 rather than information available to the producer at the time a mating was made. Cows sired by non-AI bulls comprised only $7.4 \%$ of the 2.4 million cows used in this portion of the study. DHI records indicate that producers use non-AI bulls as service sires for lactating cows much more frequently than daughters of such bulls appear in these data. These data were from herds that classified at least once in the 1980's, and such herds may make greater use of AI bulls than all herds. However, many records on progeny of non-AI bulls never enter USDA lifetime history files because of missing identification information. Furthermore, sires of cows in the study were required to have genetic evaluations based on progeny. Many natural service bulls do not obtain the required ten daughters to pass USDA editing procedures for publication. Over $79 \%$ of the cows in these data were sired by bulls in AI service and over 6 years of age at the time of daughter conception.

RNIOC reflects the ability of cows to use herd resources to generate net income relative to an average replacement from that herd. Cows with positive RNIOC were more efficient at generating a net return from available herd resources than an average replacement would have been, while resources made available to cows with a negative RNIOC would have been more efficiently used by an average replacement than by such cows. Average daughters of AI-proven bulls were more profitable (or efficient) across their lifetimes than average daughters of non-AI bulls by $\$ 148$ using fluid milk market prices and by $\$ 120$ with manufactured milk prices. This extra income is the economic benefit from the investment required to produce AI rather than natural service replacements. That investment may not be the same within-herd for AI or natural service daughters, but differences in such costs are not included in RNIOC. The $\$ 148$ difference for RNIOCF may understate the relative value of $\mathrm{AI}$ and non-AI sired cattle, as OC is affected by the genetic merit of other cows in 
Table 2. Least squares contrasts between daughters of different groups of bulls for relative net income adjusted for opportunity cost and other lifetime performance traits of $2,493,586$ cows. $^{1}$

\begin{tabular}{|c|c|c|c|c|}
\hline \multirow[b]{2}{*}{ Variable } & \multicolumn{4}{|c|}{ AI status of sire } \\
\hline & $\begin{array}{l}\text { Non-AI } \\
\text { bull }\end{array}$ & $\begin{array}{l}\text { AI bull } \\
<4 \text { yr old }\end{array}$ & $\begin{array}{l}\text { AI bull } \\
4-6 \text { yr old }\end{array}$ & $\begin{array}{l}\text { AI bull } \\
>6 \text { yr old }\end{array}$ \\
\hline Number of cows & 184,492 & 279,485 & 50,021 & $1,979,588$ \\
\hline Relative net income adjusted for opportunity cost (\$) & & & & \\
\hline Using milk values in a fluid milk market & -148 & -60 & -88 & 0 \\
\hline Using milk values in a manufacturing milk market & -120 & -54 & -73 & 0 \\
\hline Months of productive life ${ }^{2}$ & -1.02 & -0.84 & -0.94 & 0 \\
\hline Lifetime total milk, $\mathrm{kg}^{3}$ & -1460 & -932 & -1120 & 0 \\
\hline Lifetime total fat, $\mathrm{kg}^{3}$ & -52 & -35 & -39 & 0 \\
\hline Lifetime total protein, $\mathrm{kg}^{3}$ & -43 & -29 & -34 & 0 \\
\hline
\end{tabular}

the herd. If herd-year-seasons (HYS) contain a predominance of non-AI sired, OC for the HYS may be reduced relative to HYS where more AI sired cows appeared. HYS containing a predominance of AI sired cows may generate higher OC for the same reason, while herds with mixed reproductive management might generate an intermediate OC, but more variable RNIOC because of the method used to determine OC.

We fit genetic merit of sires of cows within groups in an analysis not shown, and obtained significant regressions of RNIOC on sire merit within all groups. Thus, use of carefully selected AI-proven bulls and non-AI bulls of poor pedigree merit would magnify the differences reported in Table 2. Likewise, use of mediocre proven AI bulls and non-AI bulls carefully selected on pedigree merit would diminish or even reverse differences between groups of bulls. The decision to use AI rather than natural service has an impact on net income, but selection of better bulls remains critical to optimization of returns from a breeding program.

Daughters of AI-proven bulls had more months of productive life and produced more lifetime total milk, fat, and protein than daughters of bulls in any of the other three groups. Daughters of AI bulls in sampling at time of use (AI bulls $<4 \mathrm{yr}$ old) were the second most profitable of the four groups, but generated, on average $\$ 60$ less lifetime-relative net-income adjusted for opportunity cost than daughters of AI bulls with proofs at time of use. This $\$ 60$ can be viewed as income forfeited by foregoing the increased accuracy of selection resulting from progeny test results in sire selection. Our purpose in creating the 4 to 6 -yr-old group was to prevent them from affecting comparisons of AI sample sires with proven AI bulls, rather than to evaluate the utility of such a group for genetic improvement. However, some producers do use AI bulls with only pedigree data available well after sufficient services have been per- formed for progeny test. Cassell et al. (1992) reported that heavily-used, AI-young sires were only marginally superior to all AI sample sires. Results of this study show that bulls used beyond the sampling period, but prior to progeny test results, produced slightly less profitable daughters than AI young sires used during their progeny testing period. Such bulls were not selected as accurately or intensely as proven AI bulls, and were genetically inferior to AI sample sires, presumably due to genetic trend.

\section{Future Profit from Sire Selection Decisions}

Most producers are interested in improving several traits at one time through sire selection, but may not be aware of the impact of selection for some of those traits on profitability of the resulting daughters. We wanted to show producers the impact of different sire selection approaches by predicting RNI using combinations of genetic evaluations for different traits on sires. RNI was used as the response variable because our intent was to predict future net income. RNI does not account for alternative uses of the same resources, as does RNIOC (Van Arendonk, 1990). However, RNI predicted from two different sire selection policies could be used as "opportunity cost" to each other. Care should be taken in interpreting predictions of future RNI without consideration of an alternative use of the same resources.

Table 3 includes three prediction equations each for RNI in fluid and manufactured milk markets based on genetic evaluations of the sire of the cow. Model 1 in Table 3 includes only those traits evaluated by AIPL from DHI data, milk, fat, protein, PL, and SCS. Model 2 includes those five traits and all 16 linear type traits evaluated by Holstein Association at the time of this study. Model 2 is affected by multiple co-linearity, as 
Table 3. Prediction of Relative Net Income (without adjustment for opportunity cost) using genetic evaluations for production and linear type traits on sires of $2,136,142$ Holstein cows. ${ }^{1}$

\begin{tabular}{|c|c|c|c|c|c|c|c|}
\hline \multirow[b]{3}{*}{ Trait evaluated on sire } & \multirow{3}{*}{$\begin{array}{l}\text { Annual } \\
\text { Genetic } \\
\text { trend }^{3}\end{array}$} & \multicolumn{6}{|c|}{ Partial regression coefficients } \\
\hline & & \multicolumn{3}{|c|}{ Fluid milk market prices } & \multicolumn{3}{|c|}{$\begin{array}{c}\text { Manufacturing milk } \\
\text { market prices }\end{array}$} \\
\hline & & Model 1 & Model 2 & Model 3 & Model 1 & Model 2 & Model 3 \\
\hline PTA milk, $\mathrm{kg}$ & 62.21 & 0.49 & 0.46 & 0.49 & 0.18 & 0.15 & 0.18 \\
\hline PTA fat, $\mathrm{kg}$ & 1.49 & 1.26 & 1.70 & 1.48 & 1.15 & 1.50 & 1.32 \\
\hline PTA protein, kg & 1.92 & -2.62 & -3.86 & -3.55 & 4.10 & 3.20 & 3.44 \\
\hline PTA productive life & 0.08 & 14.18 & 14.84 & 14.73 & 9.44 & 9.98 & 9.89 \\
\hline PTA somatic cell score & -0.002 & $20.65^{2}$ & $6.25^{2}$ & $18.05^{2}$ & 18.46 & $5.38^{2}$ & $14.47^{2}$ \\
\hline STA stature & 0.09 & & -29.29 & -16.47 & & -20.41 & -10.57 \\
\hline STA strength & & & 101.84 & & & 78.02 & \\
\hline STA body depth & 0.07 & & -64.68 & 24.44 & & -51.76 & 16.50 \\
\hline STA dairy form & 0.13 & & 58.09 & 23.69 & & 43.41 & 17.06 \\
\hline STA rump width & 0.07 & & 11.97 & 13.77 & & 9.64 & 11.01 \\
\hline STA rump angle & -0.01 & & 6.94 & 14.80 & & 5.68 & 11.65 \\
\hline STA rear leg side view & -0.02 & & 4.13 & 6.20 & & 3.63 & 5.23 \\
\hline STA rear leg rear view & 0.11 & & -7.44 & -4.21 & & -5.71 & -3.24 \\
\hline STA foot angle & 0.07 & & 5.44 & 5.33 & & 3.67 & 3.60 \\
\hline STA fore udder attachment & & & -11.03 & $\ldots$ & & -8.45 & $\ldots$ \\
\hline STA rear udder height & & & $-1.11^{2}$ & & & $-0.63^{2}$ & \\
\hline STA rear udder width & 0.14 & & $10.96^{2}$ & 12.70 & & 8.43 & 9.98 \\
\hline STA udder cleft & 0.11 & & $-3.80^{2}$ & $-0.78^{2}$ & & $-2.78^{2}$ & $-0.46^{2}$ \\
\hline STA udder depth & 0.07 & & $7.08^{2}$ & $-3.03^{2}$ & & $3.69^{2}$ & -4.01 \\
\hline STA teat placement & 0.09 & & $1.26^{2}$ & $0.52^{2}$ & & $0.41^{2}$ & $-0.18^{2}$ \\
\hline STA teat length & 0.01 & & $-3.40^{2}$ & -3.76 & & $-2.38^{2}$ & -2.65 \\
\hline Coefficient of determination ${ }^{4}$ & & 0.160 & 0.160 & 0.160 & 0.177 & 0.178 & 0.178 \\
\hline
\end{tabular}

${ }^{1}$ Effects of herd-year of first freshening were absorbed in the analysis. Standard transmitting abilities (STA) for linear type traits are unit normal variables.

${ }^{2}$ Not significant. Other partial regression coefficients were significantly different from $0.00(P<0.01)$.

${ }^{3}$ Genetic trend estimated from linear regression of birth year on mean PTA's for bulls born in the 10 most recent years of birth available. Units are kg for yield traits.

${ }^{4} \mathrm{R}^{2}$ values for herd-year of first freshening alone were 0.143 for fluid milk market prices and 0.160 for manufacturing milk market prices.

several of the linear type traits are highly correlated (Weigel et al., 1997). Model 3 removes body depth, fore udder attachment, and rear udder height from Model 2 as suggested by Weigel et al. (1997), because of multiple co-linearity problems with other traits and is the preferred prediction equation for future RNI with linear type data included.

Table 3 also includes estimates of genetic trend per year among bulls for the traits evaluated on sires, as these estimates are necessary to predict genetic merit of bulls that would be chosen by the same selection criteria 5 or 10 years in the future. Trend estimates were from the linear regression of average genetic evaluation by year of birth (Animal Improvement Programs Laboratory, 2000; Klei, 2000) on year for all Holstein bulls evaluated by AIPL or the Holstein Association. We used the most recent 10 years' of information available, as rates of genetic progress for some traits changed over time. Estimates of genetic trend were necessary to project alternative sire selection policies into the future. For instance, one sire selection policy might include bulls that averaged 1.0 for udder depth, while another included bulls that averaged 0.0. The estimate of ge- netic trend for udder depth, +0.07 STA units per year, could be used to increment those initial averages over a planning horizon of 10 years. Similar initial values, estimates of genetic trend, and regression coefficients for the other traits in Model 3, will predict (and plot graphically) RNI for those two sire selection strategies for the next 10 years. Differences in RNI for the two policies could be used to demonstrate the benefit (or lack of benefit) of an extra STA unit of udder depth in service sires. All predictions would depend on average sire merit for the other traits in Model 3 as well, thus evaluating the overall effect of sire selection decisions, including correlated responses. Intercepts for predictions from Model 3 are $\$ 1746$ for RNI in a fluid market and $\$ 885$ for RNI in a manufactured milk market. These intercepts are appropriate for sire evaluations calculated relative to the genetic base formed by cows born in 1995 .

Herd and year of first freshening alone produced $R^{2}$ of .143 and .160 for fluid and manufactured milk market prices, respectively. Genetic evaluations of sires of these cows, while significant, did not explain much of the remaining variation between cows for RNI within 
herd and year of first freshening. There are several reasons for this result. Heritability of RNI in fluid and manufacturing milk markets (without adjustment for opportunity cost) is 15\% (Smith et al., 1998). Much of the variation in profit functions for these cows is controlled by factors other than additive gene action. Genetic merit of the sire only partly controls half of the additive variation, as all gene samples transmitted to daughters are subject to mendelian segregation. Predictions of RNI are based on the traits listed for each model in Table 3, and other traits such as disease resistance and reproduction are not included but also affect genetic control of RNI. Finally, the accuracy of PTA's for traits in Table 3 affect $R^{2}$ values. Genes transmitted to each daughter are a random sample from the true breeding value of each sire, which is estimated with imperfect accuracy by PTA for each trait.

Partial regressions for production traits in Table 3 change considerably for RNI using fluid milk market or manufacturing milk market prices. Partial regressions for protein are negative for fluid markets, but positive for manufacturing milk markets. The RNI function includes a cost to produce protein under both markets, but protein generates revenue only in the manufactured milk market. Producers shipping milk to fluid markets face such economic conditions. AI bulls with high PTA for protein and premium semen prices may be more appropriate choices for producers who ship milk to manufactured milk markets than for producers shipping to fluid milk markets.

Models 1 and 2 in Table 3 show that linear type data added very little to the accuracy of prediction of RNI. $\mathrm{R}^{2}$ values increase only slightly under manufactured milk market prices, and not at all for fluid milk market prices. These results are consistent with Weigel et al. (1997), who reported that lower milk prices under manufacturing milk market conditions increased the relative value of functional type and fitness traits. Genetic evaluations for PL for these bulls were heavily influenced by direct evaluations of PL on progeny, because of the age of the data. This effect may reduce the relative value of linear type information compared to bulls with progeny not yet old enough for direct expression of herdlife. Models 2 and 3 reflect the effect of multiple colinearity on partial regression coefficients for pairs of highly correlated traits such as stature, strength, and body depth or fore udder attachment, rear udder height and width, and udder depth. Elimination of strength, fore udder attachment and rear udder height changed size and sometime sign of partial regressions for remaining traits with no reduction in $\mathrm{R}^{2}$. For instance the partial regression coefficient for body depth predicting RNIM changed from -51.76 to 16.50 and stature changed from -20.41 to -10.57 with the elimination of strength. Partial regressions for SCS were also affected by elimination of linear traits, but SCS was significant for only one of the six models in Table 3. SCS on individual cows was not used to calculate RNI in this study and would only improve accuracy of prediction through correlated effect on yields, length of productive life, reproduction and so forth. A more realistic evaluation of actual costs and returns from SCS would charge for treatment of mastitis and discarded milk and reward cows with low SCS for milk quality premiums.

\section{Accuracy of Merit Indexes}

Animal Improvement Programs Laboratory published three selection indexes in August 2000 (VanRaden, 2000) that were structured to improve lifetime economic merit of dairy cows. Net, Fluid, and Cheese Merit were intended for producers selling milk to markets that price milk according to use for a variety of milk products, predominantly for fluid consumption, or for the production of cheese, respectively. The lifetime economic merit functions we used did not mimic cheese market conditions, and we chose to study Net and Fluid Merit only. Those indexes had not been released when this study was conducted, but the formulas were available. We calculated Net and Fluid Merit indexes on the 6663 Holstein bulls represented in the data. Net and Fluid Merit averaged $-\$ 40$ and $-\$ 29$ with standard deviations of $\$ 171$ and $\$ 179$ respectively. By contrast, average Net Merit for active AI Holsteins in February 2002 averaged $\$ 338$ with a standard deviation of $\$ 139$. The difference in mean reflects genetic progress in the Holstein bull population between birth of sires of cows in this study and current active AI bulls, while smaller variation in Net Merit for current active AI bulls likely results from selection decisions by bull studs based on market potential.

Table 4 includes regression coefficients for prediction of RNIOC for fluid or manufactured milk prices using the eight traits or composites of linear type traits used in the Merit indexes. We used RNIOC in this analysis as our purpose was to predict lifetime economic merit calculated from existing data, and we did not intend to use the results to predict future lifetime economic merit. Table 4 contains two prediction equations each for fluid and manufactured milk market prices, one based on cows in herds with even DHI herd code numbers and the other from cows in odd numbered herds. Partial regression coefficients and $R^{2}$ values were similar from odd and even herds within fluid or manufactured milk price assumptions. Partial regression coefficients for somatic cell score did change, but were never significantly different from $0.0(P>0.01)$ in any of the four prediction equations. SCS for individual cow rec- 
Table 4. Regression coefficients for prediction of lifetime net income adjusted for opportunity cost on separate data sets (odd and even herd code numbers) created from 2,136,142 Holstein cows. Variable used in predictions were sire evaluations for the traits included in USDA Merit indexes.

\begin{tabular}{|c|c|c|c|c|}
\hline \multirow[b]{2}{*}{ Trait or composite } & \multicolumn{2}{|c|}{$\begin{array}{l}\text { Relative net income adjusted for } \\
\text { opportunity cost using } \\
\text { manufacturing milk market prices }\end{array}$} & \multicolumn{2}{|c|}{$\begin{array}{l}\text { Relative net income adjusted for } \\
\text { opportunity cost using fluid } \\
\text { milk market prices }\end{array}$} \\
\hline & $\begin{array}{l}\text { Odd numbered } \\
\text { herds }\end{array}$ & $\begin{array}{l}\text { Even numbered } \\
\text { herds }\end{array}$ & $\begin{array}{l}\text { Odd numbered } \\
\text { herds }\end{array}$ & $\begin{array}{l}\text { Even numbered } \\
\text { herds }\end{array}$ \\
\hline PTA milk, kg & 0.141 & 0.143 & 0.423 & 0.423 \\
\hline PTA fat, $\mathrm{kg}$ & 0.562 & 0.439 & $0.075^{1}$ & $-0.108^{1}$ \\
\hline PTA protein, kg & 3.878 & 3.937 & -3.142 & -3.018 \\
\hline PTA productive life & 46.736 & 46.532 & 50.328 & 50.017 \\
\hline PTA somatic cell score & $6.253^{1}$ & $0.807^{1}$ & $0.939^{1}$ & $-5.423^{1}$ \\
\hline PTA udder & -10.492 & -8.347 & -15.634 & -12.544 \\
\hline PTA feet and legs & -10.922 & -13.334 & -13.275 & -15.994 \\
\hline PTA size & 19.904 & 20.039 & 21.884 & 21.359 \\
\hline $\mathrm{R}^{2}$ & 0.091 & 0.092 & 0.100 & 0.103 \\
\hline Number of cows in data & $1,068,358$ & $1,067,784$ & $1,068,358$ & $1,067,784$ \\
\hline
\end{tabular}

${ }^{1}$ Not significantly different from $0.0(P>0.01)$.

ords were not considered in calculation of lifetime economic merit due to missing SCS data (Smith et al., 1998). Partial regressions for PTA protein differed in sign for manufactured or fluid milk market price assumptions, as explained earlier. Partial regressions for PTA milk were larger with fluid than with manufactured milk prices, and partial regressions for PTA fat were not significantly different from $0.0(P>0.01)$ under fluid milk market prices. Partial regressions for production traits in Table 4 reflect the differences in market values and costs of production, and the genetic co-variances between all traits included as independent variables. Partial regressions for type composites were generally similar in size and sign for all analyses, but attempts at biological interpretation of the results are probably unjustified. Weigel et al. (1997) showed that linear type traits explained only small amounts of variation in profit functions calculated similarly to the ones used in this study.

The partial regression coefficients in Table 4 differ from the weights used in Net Merit calculations (VanRaden, 2000) for many reasons. RNIOC accounts for opportunity cost for each herd-year in which a cow has a calf and for each day of life from first calving to culling or death. Net Merit does not include opportunity cost, but may consider the effect of adjustment for it if selection index weights were based on studies that considered opportunity cost. Both Net and Fluid Merit use milk valued at $\$ 28.00 / 100 \mathrm{~kg}$, whereas we used prices of $\$ 25.35 / 100 \mathrm{~kg}$ for manufactured milk market and $\$ 28.87 / 100 \mathrm{~kg}$ for fluid milk market conditions (Smith et al., 1997). Selection index weights used in the Merit indexes were marginal economic values (other traits held constant) from reports in the literature. Partial regression coefficients in Table 4 are least squares solu- tions. The economic assumptions that affect RNIOC were applied to lifetime performance records on individual cows, rather than to genetic evaluations of bulls. Results in Table 4 should not be expected to agree with weights used in Merit indexes, but the different approaches can be compared as an independent measure of the utility of USDA Merit indexes.

Table 5 contains results of prediction of RNIOC on individual Holstein cows using different evaluations of lifetime economic merit from genetic evaluations on their sires. We used the least squares solutions from odd numbered herds to predict RNIOC on sires of cows in even numbered herds and then tested that prediction of lifetime economic merit on the sire by predicting actual RNIOC calculated for the cows. We also used the Net or Fluid Merit index of each cow for the same purpose. For instance, the regression of $\$ 1.03$ in the first cell indicates that RNIOC calculated using manufactured milk prices on cows in odd numbered herds increased by $\$ 1.03$ for each $\$ 1.00$ increase in predicted RNIOC for manufactured milk prices when using the prediction equation developed using cows in even numbered herds. $\mathrm{R}^{2}$ for that prediction was 0.091 . The regression coefficients in Table 5 were closer to $\$ 1.00$ when RNIOC using manufactured milk market prices was predicted from an equation based on the same economic assumptions and vice versa. Regressions using Net or Fluid Merit were always less than $\$ 1.00$. If these lifetime economic merit functions include and properly value all important sources of income and expense in the life of a dairy cow, then the Merit indexes overstate absolute profitability of progeny.

Our purpose in the analysis reported in Tables 4 and 5 was to evaluate the accuracy of the Merit indexes relative to some alternative combination of the same 
Table 5. Prediction of relative net income adjusted for opportunity cost on Holstein cows in odd and even herds using Net Merit and Fluid Merit indexes on their sires, compared to predictions from indexes using partial regressions developed from the opposite group of herds (Table 4).

\begin{tabular}{|c|c|c|c|c|c|c|c|c|}
\hline \multirow{3}{*}{ Measure of sire merit } & \multicolumn{8}{|c|}{$\begin{array}{l}\text { Prediction of relative net income adjusted } \\
\text { for opportunity cost on daughters }{ }^{3}\end{array}$} \\
\hline & \multicolumn{4}{|c|}{$\begin{array}{l}\text { Relative net income adjusted for } \\
\text { opportunity cost using } \\
\text { manufacturing milk market prices }\end{array}$} & \multicolumn{4}{|c|}{$\begin{array}{l}\text { Relative net income adjusted for } \\
\text { opportunity cost using } \\
\text { fluid milk market prices }\end{array}$} \\
\hline & \multicolumn{2}{|c|}{ Odd numbered herds } & \multicolumn{2}{|c|}{ Even numbered herds } & \multicolumn{2}{|c|}{ Odd numbered herds } & \multicolumn{2}{|c|}{$\begin{array}{l}\text { Even numbered } \\
\text { herds }\end{array}$} \\
\hline Predicted RNIOCM ${ }^{2}$ & & & $\$ 1.02$ & 0.092 & & & $\$ 1.17$ & 0.101 \\
\hline Predicted RNIOCF ${ }^{2}$ & & & $\$ 0.78$ & 0.090 & & & $\$ 1.01$ & 0.103 \\
\hline Net Merit & $\$ 0.54$ & 0.086 & $\$ 0.54$ & 0.088 & $\$ 0.58$ & 0.090 & $\$ 0.57$ & 0.094 \\
\hline Fluid Merit & $\$ 0.55$ & 0.087 & $\$ 0.55$ & 0.088 & $\$ 0.68$ & 0.096 & $\$ 0.68$ & 0.099 \\
\hline
\end{tabular}

traits. $R^{2}$ values using the Merit indexes were always smaller than $\mathrm{R}^{2}$ using predicted RNIOC in the same herds. Thus, the Merit indexes were not as accurate in predicting our profit function as were predictions derived from our profit function in a separate set of herds. The result is due, in part, to differences in milk pricing systems used in RNI and by USDA. However, the differences between $R^{2}$ values for both milk market price assumptions averaged only 0.004 for the 16 comparisons possible within odd or even herds. The results indicate that the Merit indexes were, for practical purposes, as effective as our least squares predictions in differentiating between cows for lifetime economic merit calculated by a different method that the one used to develop the Merit indexes.

\section{CONCLUSIONS}

Groups of cows sired by proven AI bulls were $\$ 148$ more profitable across their lifetimes than daughters of non-AI bulls when milk was sold in a fluid milk market and $\$ 120$ more profitable under manufactured milk market prices. Daughters of proven AI bulls survived over 1 mo longer and produced over $1400 \mathrm{~kg}$ more total lifetime actual milk yield than daughters of non-AI bulls. Selection of bulls with highest merit, regardless of AI or non-AI status, was associated with highest daughter profitability. Combinations of sire evaluations for production and functional traits can be used to compare the importance of the different traits to daughter profitability. Genetic evaluations of traits in the sire accounted for small but significant amounts of variation in RNI. Educators and industry personnel will remain challenged to convince producers that such small differences are worth the effort to achieve them.

The lifetime profit functions we used are based on assumptions of costs of specified inputs and value of specified outputs. Other costs, reductions in costs, and sources of income, such as economic value attributable to lower SCC, that are widely measured on many cows could have been used with equal justification. All such assumptions affect results in this paper. Likewise, USDA weights for the Merit indexes are based on current research information that may change in the future. Results of this study demonstrate the robust nature of the assumptions on which the present Merit indexes are based. Results show that farmers can use the Merit indexes for sire selection decisions with confidence that the aggregate genotype favored is consistent with and effective in the improvement of a breeding objective of improved lifetime economic merit.

\section{ACKNOWLEDGMENTS}

We wish to thank Cooperative Resources International, Shawano, WI for financial assistance, Holstein Association, and the Animal Improvement Programs Laboratory, USDA, Beltsville, MD for data used in this project.

\section{REFERENCES}

Animal Improvement Programs Laboratory. 2000. Genetic and phenotypic trend (1960 to present). http://aipl.arsusda.gov/eval.html\#trend. Accessed February 2000.

Cassell, B. G., 2001. Optimal genetic improvement for the high producing cow. J. Dairy Sci. 4 (July). Online. Available. http:// www.adsa.org/jds/papers/2001/jds_es144.pdf. 
Cassell, B. G., R. E. Pearson, M. L. McGilliard, and T. R. Meinert. 1992. Genetic merit and usage patterns of bulls from different sampling programs. J. Dairy Sci. 75:572-579.

Cassell, B. G., B. B. Smith, and R. E. Pearson. 1993. Influence of herd-life opportunity and characteristics of cows and herds on different net income functions. J. Dairy Sci. 76:1182-1190.

Charagu, P. K. 1997. Economic efficiency of Canadian and New Zealand sires in Canadian and New Zealand dairy herds and its relationship with other traits. $\mathrm{PhD}$ dissertation. University of British Columbia. Vancouver, B. C. Canada.

Cranford, J. L., and R. E. Pearson. 2001. Relationships of sires' predicted transmitting ability SCS and measures of daughter performance. J. Dairy Sci. 84:1501-1507.

Dado, R. G., G. E. Shook, and D. R. Mertens. 1994. Nutrient requirements and feed costs associated with genetic improvement in production of milk components. J. Dairy Sci. 77:598-608.

Ferris, T. A., and G. R. Wiggans. 1991. Accuracy of animal model parent evaluations in predicting PTA for AI sampled bulls. J. Dairy Sci. 74(Suppl. 1):265.(abstr).

Klei, L. 2000. Trends in STA for linear type traits using August 1999 linear trait evaluations. Personal communication. April 6, 2000.

Kulak, K. K. 1994. Lifetime profitability measures and their relationships to lifetime and first lactation traits in Holstein cows. Masters Thesis. Univ. Guelph, Ontario, Can.

Rogers, G. W. 1993. Index selection using milk yield, SCS, udder depth, teat placement, and foot angle. J. Dairy Sci. 76:664-670.

SAS User's Guide: Statistics, Version 6.03 Edition. 1988. SAS Inst., Inc., Cary, NC.

Smith, L. A., B. G. Cassell, and R. E. Pearson. 1998. The effects of inbreeding on the lifetime performance of dairy cattle. J. Dairy Sci. 81:2729-2737.
Van Arendonk, J. A. M. 1991. Use of profit equations to determine relative economic value of dairy cattle herd life and production from field data. J. Dairy Sci. 74:1101-1107.

VanRaden, P. 2000. Subject: Net Merit as a measure of lifetime profit (November 2000). http://aipl.arsusda.gov/memos/html/nm/ 2000.html. Accessed March 22, 2001.

VanRaden, P., and G. R. Wiggans. 2000. Multi-trait PL. http://aipl.arsusda.gov/memos/html/multipl.html. Accessed April 30, 2001.

VanRaden, P. M., G. R. Wiggans, R. L. Powell, and H. D. Norman. 1995. Changes in USDA-DHIA genetic evaluations (January 1995). http://aipl.arsusda.gov/memos/html/. Accessed April 30, 2001.

Van Vleck, L. D. 1976. Theoretical and actual genetic progress in dairy cattle. Page 547 in Proc. Int. Conf. Quant. Genet. August 16-21, 1976. Iowa State Univ. Press. Ames.

Van Vleck, L. D. 1981. Potential genetic impact of artificial insemination, sex selection, embryo transfer, cloning and selfing in dairy cattle. Page 221 in New Technologies in Animal Breeding. Acad. Press, London, England.

Vierhout, C. N., B. G. Cassell, and R. E. Pearson. 1998. Influences of progeny test programs on genetic evaluations of young sires. J. Dairy Sci. 81:2524-2532.

Weigel, D. J., B. G. Cassell, I. Hoeschele, and R. E. Pearson. 1995a Multiple-trait prediction of transmitting abilities for herd life and estimation of economic weights using relative net income adjusted for opportunity cost. J. Dairy Sci. 78:639-647.

Weigel, D. J., B. G. Cassell, and R. E. Pearson. 1995b. Adjustment of a net income function for opportunity cost of postponed replacement on a lactation basis. J. Dairy Sci. 78:648-654.

Weigel, D. J., B. G. Cassell, and R. E. Pearson. 1997. Prediction of transmitting abilities for PL and lifetime profitability from production, somatic cell count, and type traits in milk markets for fluid milk and cheese. J. Dairy Sci. 80:1398-1405. 